DOI:

UDC 340.1

Edyta Sokalska,

dr hab., Law and Administration Faculty

University of Warmia and Mazury in Olsztyn,

Poland

ORCID: https://orcid.org/0000-0003-0903-7726

\title{
THE DEVELOPMENT OF DELIBERATIVE DEMOCRACY AND POST-COMMUNIST POLISH EXPERIENCE (SOME REMARKS)
}

The concepts of deliberative democracy, which emerged on a large scale in the 1980s, has become the subject of the scientific discussion on various fields. The flaws of representative democracy and the lack of legitimization of political systems led to the development of research on the improvement and modification of quality of democracy. Participatory democracy emphasized the broad participation of citizens in decision-making process, while deliberative (discursive) democracy indicated deliberation as essential, where political decisions should have been the product of fair and reasonable discussion and dialogue. The fall of communism and the elimination of some considerable threats connected with this kind of political regime brought the different attitude to the liberal democracies in post-communist states. Political changes in Poland in the late $80 \mathrm{~s}$ and $90 \mathrm{~s}$ of the 20th century led to the development of the new political regime. That process concerned the decentralization of powers, and consequently led to the creation of a new civil society, where local self-government was reintroduced by the reforms of public administration. The main institutions improving the development of the Polish civic society at the local level became local election, referendum, social consultations, civil (participatory) budget, and the possibility of civil participation in the debate on the report referring to the condition of the local administrative unit, and the civil legislative initiative.

Keywords: participation, legitimization, political system, self-government, decentralization, civic society

Sokalska $E$.

Rozwój demokracji deliberacyjnej i polskiego doświadczenia postojowcowego (niektóre uwagi)

Pojęcie demokracji deliberatywnej, które na szersza skalę zaczęło być rozpatrywane w latach 1980, stało się przedmiotem dyskusji naukowych podejmowanych $w$ różnych dziedzinach wiedzy. Wady demokracji reprezentacyjnej oraz brak legitymizacji władzy przyczynity się do rozwoju zainteresowania oraz badań nad modyfikacja dotychczasowego modelu demokracji. Demokracja partycypacyjna uwypukla szerokie uczestnictwo obywateli w procesie podejmowania decyzji, podczas gdy demokracja deliberatywna (dyskursywna) podkreśla deliberację $i$ dyskurs jako niezbędna podstawę demokracji, gdzie decyzje polityczne powinny być produktem uczciwego i rozsądnego dialogu i dyskursu. Upadek komunizmu i eliminacja zagrożeń z nim związanych zaowocowały innym podejściem do kwestii liberalnej demokracji w krajach postkomunistycznych. Zmiany polityczne lat mające miejsce w późnych latach 80. i 90. XX w. przyczynity się do powstania nowego systemu politycznego. Proces ten wiąat się z decentralizacja władzy $i$ w konsekwencji doprowadzit do ewolucji społeczeństwa obywatelskiego, gdzie wprowadzono ponownie samorzad terytorialny dzięki reformom administracji publicznej. Głównymi instytucjami, które przyczynity się do zmian w kierunku budowania społeczeństwa obywatelskiego na poziomie lokalnym, stały się wybory do władz samorzadowych, referendum, konsultacje społeczne, budżet obywatelski, wystapienie przez mieszkańców jednostki z inicjatywą ustawodawcza oraz możliwość udziału mieszkańców jednostki samorządu terytorialnego $w$ debacie nad raportem o stanie tej jednostki.

Stowa kluczowe: partycypacja, legitymizacja, system polityczny, samorząd terytorialny, decentralizacja, spoteczeństwo obywatelskie

\section{Сокальска E.}

Розвиток свідомої демократії та посткомуністичний досвід Польщі (окремі зауваги)

Кониепиії свідомої демократії, щзо виникли у 1980-х роках, стали предметом наукової дискусї̈ у різних сферах. Недоліки представницької демократії та відсутність легітимізації політичних систем призвели до розвитку досліджень щзодо поліпшення і модифікаиії якостей демократії. Демократія, щяо бере участь, наголошувала на широкій участі громадян у прочесі прийняття рішень, тоді як наочна (дискурсивна) демократія вказувала на обговорення як на важливе значення, коли політичні рішення повинні бути результатом чесного та розумного обговорення і діалогу. Падіння комунізму та усунення деяких значних загроз, пов'язаних з таким політичним режимом, призвели до різного ставлення до ліберальних демократій у посткомуністичних державах. Політичні зміни в Польщзі наприкінці 80-х та 90-х років ХХ cm. зумовили розвиток нового політичного режиму.

(c) Edyta Sokalska, 2019 
Sokalska E.

Ehe development of deliberative democracy and post-communist polish experience (some remarks)

Цей прочес стосувався децентралізачії повноважень, а отже, привів до створення нового громадянського суспільства, де місиеве самоврядування було запроваджене реформами державного управління. Основними інститутами, щзо покращують розвиток польського громадянського суспільства на місцевому рівні, стали місцеві вибори, референдум, соиіальні консультаиії, громадський (за участю) бюджет та можливість участі громадян у дискусіях щуодо звіту, які стосуються стану місцевої адміністративної одиниці та ичивільної законодавчої ініціативи

Ключові слова: участь, легітимізація, політична система, самоврядування, децентралізація, громадянське суспільство.

Purpose of the study. Political changes in Poland in the late 80s and 90s enabled the evolution of a new political regime The development of the civil society in the 21 st century stimulates some questions concerning the instruments and forms of the effective deliberation and participation. The appropriate identification and application of deliberative and participatory instruments may strengthen the legitimization of political decisions. The purpose of the article is the presentation of the Polish experience concerning the improvement of public administration at the local level. The main questions the present study strives to answer are: What stimulated the scientific reflection over the new forms of democratic systems in order to legitimize political decisions? What are the modern forms of public participation at the local level in Poland?

Research methods. In this particular study theoretical analysis, historico-descriptive, and legal methods (including formal legal method) were applied to approach the raised questions and to formulate conclusions.

Literature overview. With the collapse of the bipolar world, which was dominated by the United States and Russia, there appeared a variety of prognostic theories about the world of politics. In my opinion, the most popular theories are derived from the American academia, and they include the thoughts of Samuel P. Huntington [20; 21], Francis Fukuyama [16; 17], John Rawls [28], and Alvin Toffler [33; 34]. Regardless of the differences among these authors as far as their diagnoses are concerned, their predictions were based on a rich factual material that predicts (to some extent) the future. In turn, in the case of European researchers, it is significant the existence of a demanded attitude that is determined by the 'duty', and the creation of abstractive phenomena as presented by Jürgen Habermas [18; 19, pp. 411-426], Niklas Luhmann [24], or Zygmunt Bauman [1].

The literature concerning the development of deliberative democracy is as impressive as the phenomenon it describes. The representatives of science try to answer the question how to make political authority trustworthy and legitimate. The publications of John S. Dryzek influenced the scientific and social reception of the phenomenon, and the works of James S. Fishkin are also of high importance. It is also interesting to consider that such eminent philosophers as Jürgen Habermas [18] and John Rawls [28] emphasize the value of communication in a community as a sphere, in which an autonomous individual has the opportunity to engage in common values and maximize the agreement through communication.

In the field of Polish science, the publications of Tomasz Schimanek [29], Grzegorz Makowski [25], Anna Krajewska [22], Piotr Uziębło [40], Marzena Mendza-Drozd [27], Mariusz Wiktor Sienkiewicz and Monika Sidor [31], Katarzyna Kuć-Czajkowska and Justyna Wasil [23], Zbigniew Zychowicz [41], and others can be mentioned here. It is also crucial to emphasize the importance of the reports of some research teams in the programs financed by the European Union.

Research and discussion. On a large scale the crisis of contemporary democracy is present in the academic discourse since the 70s of the 20th century [5, pp. 1-212; 4, pp. 1-229]. The reflection of political science of the last decades of the 20th century focused on the research concerning the 'internal' and 'external' problems of representative democracy, often contrasted with the direct democracy. A number of charges against representative democracy includes: a decrease in political activities and voter turnout; an increase of alienation and cynicism of citizens; the lack of enthusiasm and confidence in political institution; a disproportion in participations as the effect of excluding people living on the margins of society; disappearance of some social bounds; the lack of legitimization of political systems due to the fact that political decisions taken at multi-level stages made the identification of the responsibility of the decision makers almost impossible [26, p. 109]. It is significant that there were more unfavorable conditions which also influenced the quality of contemporary democratic systems, e.g., the destructive influence of globalization on the local markets and traditional social bonds, economic changes leading to the treatment of social relations as the economic phenomena; demographical trends connected with the ageing of societies; the individualization of life resulting in degeneration of social bonds; decrease in the role of the states authorities, their responsibilities as a result of globalization and mass migration; a sense of thread with work market transformation and fluctuation; or some changes in social structures resulting from the dynamic evolution [26, p. 111]. 
It is significant that the development of interest in the direct democracy was influenced by the above mentioned flaws of representative democracy. Unfortunately, despite some appreciated merits of the direct democracy, practice and expert reflection unveiled some serious limitation of this political regime. The consequence of the disappointment with both representative and direct democracy was a great number institutional of innovations aiming at the improvement and modification of quality of democracy. In 1980s, there appeared a number of initiatives, which oscillated around some new economic, technological, and communicative factors, which might have influenced and ameliorated the forms of democratic regimes. The ideas of participatory democracy and deliberative democracy developed in order to modify and improve democratic regimes. Participatory democracy emphasized the broad participation of citizens in decision-making process, while deliberative (sometimes called discursive) democracy indicated deliberation as essential, where political decisions should have been the product of fair and reasonable discussion and dialogue.

The concept of deliberative democracy emerged on a large scale in the 1980s, and it has rapidly become the subject of the scientific discussion on philosophy of law, and political and sociological thought. It is significant that the term of deliberative democracy currently denotes some views combined together under the aegis of the idea that social deliberation is central to the democratic decision making. The popularizer of the term of deliberative democracy became John S. Dryzek who put forward the thesis that the deliberative turn in the theory of democracy took place in the last decade of the 20 th century $[9$, p. $1 ; 8 ; 11]$. The process was conceived in terms of the legitimacy of democracy, thanks to participation of citizens in active deliberation as a part of collective decisionmaking. In his opinion, that emphasis on deliberation is not a new phenomenon because its antecedents can be found in ancient Greece, in political theory of Edmund Burke, John Stuart Mill, and theorists from the early 20 th century such as John Dewey. Invented by Joseph Bessette [2, pp. 102-116] and popularized by Bernanrd Manin and Joshua Cohen, the term of 'deliberative democracy' was used rarely prior to 1990s [9, p. 2].

In the reception of Dryzek the final decade of the 20th century was the time when the theory of democracy takes a strong deliberative turn, and democratic legitimacy was seen «in terms of the ability or opportunity to participate in effective deliberation on the part of those subject to collective decision. (Note that only the ability or opportunity to participate is at issue; people can choose not to deliberate.) Thus claims on behalf of or against such decisions have to be justified to these people in terms that, on reflection, they are capable of accepting» $[9, \mathrm{p} .1 ; 10$, p. 145]. Deliberation for Dryzek is a social process distinguished from the other forms of communication, open to the possibility of changing positions, preferences or views through interactions between participants of deliberation during its duration [7, pp. 634-649]. Deliberative democracy is a reform movement and an academic activity [13, p. 241]. In the opinion of Dryzek, such philosophers as Habermas or Rawls are the most important liberal theorists and critical theorists of the late 20th century, whose works highly influenced the modern vision of deliberative democracy. He also states that deliberative democracy can be placed fairly close to discursive democracy, but they are not synonyms, and «the deliberative turn represents a renewed concern with the authenticity of democracy: the degree to which democratic control is substantive rather than symbolic, and engaged by competent citizens» [9, p. 1; 12, pp. 1379-1402].

It should be taken into account that other American scholar - James S. Fishkin - treats deliberative democracy as a natural consequence of representative democracy [14, pp. 1-144]. He emphasizes that «much of the history of democratic reform has focused on the extension of political equality to groups that were previously left out because of race, ethnicity, religion, economic status, or gender. These extensions of the franchise are very great accomplishments» [15, p. 48]. Thanks to them, the range of citizens, to whom equal consideration posited by political equality, has increased. Fishkin argues that the expansions of political equality were accompanied by increased opportunities for political participation combining two fundamental values: «the primary direction of democratic reform not only in the United States but in most of the major Western democracies has been a simultaneous movement in the direction of both increasing political equality and increasing opportunities for mass participation» $[15$, p. 48]. However, according to Fishkin, opening up political processes to facilitate mass participation has had an unexpected effect of lessening the realization of the third key value - deliberation.

The fall of communism and the elimination of some considerable threats connected with this kind of political regime brought the different attitude to the liberal democracies in post-communist states. In 'old' and 'new' democracies we can observe the intensified social individualism, the degradation of family and moral values, and the lack of confidence in political class. The academic research and scholar reflection devoted to representative democracy appeared in order to find new some criteria of democracy. Some of the solutions of deliberative democracy were willingly adopted in post-communist countries in order to meet new social and political needs. 
Sokalska E.

Ehe development of deliberative democracy and post-communist polish experience (some remarks)

Political changes in Poland in the late 80 s and 90 s led to the development of the new political regime. That process concerned the decentralization of powers, and consequently led to the creation of a new civil society. Local self-government was reintroduced by the reforms of public administration of 1990s [39; 38]. It referred, in the matter of fact, to some Polish historical experience of the interwar period, or even earlier. Therefore, the dualistic model of public administration was developed. It is significant that local self-government was regarded as the expression of the civic society. The existence of local self-government is recognized as the crucial expression of the decentralization of public administration, which goes beyond the local interest [35, p. 35].

The main institutions improving the development of the Polish civic society at the local level became local election, referendum and social consultations. Granting local citizens the ability of influence on the decisions the local community via election and referendum arises from the articles of the Polish Constitution and the legal acts referring to self-government [3, p. 100]. It is significant that social consultations do not result directly from the Constitution but from the catalogue of participatory forms presented in the self -government laws. This form of participation in the local decisive process appeared in the self-government rules of 1996 and 2001 [36]. It was considered that the process of public participation via social consultations should have strengthened the involvement of citizens in the public sphere of life at the local level. The motivation to implement social consultations into Polish ground results, in fact, from the internal and external pressure. The external pressure arises from the EU requirements and standards. Social consultations at the level of gmina administrative district are of obligatory or facultative character [37]. Obligatory character of consultations results from the legal acts devoted to the local administrative units. Facultative consultations may be decided in the important, from the local perspective, matters. They may also depend on the object of consultations and relate to some part of society. The Polish legislator entitled local administrative units (gmina) to determine the forms, procedure, and rules of consultations.

It should be emphasized that the mentioned above forms of realization of local democracy allow to consider the legal capacity of the local communities to perform public authority. The local members of the society are able to influence the course of local events thanks to their three key entitlements: via election they can choose their representatives; via local referendum they may decide some substantive matters [30, pp. 186-194]; via social consultations they can present their opinions and postulates concerning some specific activities of the local bodies. Ratio legis of the legislator was to enhance the participation of the members of the local communities in the decisive process, and consequently in the exercising the authority. The essence of the social consultations comes down to the permanent dialogue between the local self-governmental bodies and the members of the local society. As far as social consultations are concerned, the point is not only to know the opinion of inhabitants of the local administrative district, but also to recognize the solutions proposed by them. Only such bidirectional vision of consultations is efficient from the view of the civil society. If social consultations are the real bidirectional exchange of dialogue and information, local communities are able to identify true expectations of their citizens and therefore the undertaken decisions are more optimal and legitimized.

It should be taken into consideration that currently local self-governmental bodies in Poland strive to develop some new forms and tools of communication to make social consultations more efficient [41, p. 172]. Meetings of inhabitants, survey forms, meetings of the local authorities and local representatives with the inhabitants of local administrative districts, research on public opinion using some electronic questionnaires, consultation cards, and receiving opinions and proposals are common forms of consultations at the local level are [6, pp. 23-25]. Information and communication technologies shape public opinion and the subjectivity of citizens. They give the opportunity to faster exchange of information and answers to the local problems.

The newly created legal act - Ustawa z dnia 11 stycznia 2018 r. o zmianie niektórych ustaw w celu zwiększenia udziału obywateli w procesie wybierania, funkcjonowania i kontrolowania niektórych organów publicznych [37] amends the law of 1990 concerning the local self-government, and it improves the development of Polish participatory democracy at the local level. The purpose of the amendment was to enhance the participation of citizens and to make deliberation more efficient. The way to obtain this aim was the increase of public participation in the process of election, functioning, and controlling self-government local bodies. Some legal mechanisms were introduced in order to widen the number of members of local communities in their operations and functioning connecting with performing some public tasks via self-governmental bodies. It is worth to emphasize that on the basis of the changes introduced by the amendment the accents of representative democracy were replaced with the solutions of deliberative democracy. Civil (participatory) budget, the possibility of civil participation in the debate on the report referring to the condition of the local administrative unit, and the civil legislative initiative according to the amendment became the institutions, which serve in order to enhance the scope of the Polish civil society.

Conclusions. Some noticeable flaws of representative democracy in the 20th century stimulated the scientific research on the deliberative and participatory forms of public dialogue. The broad participation of citizens in deci- 
sion-making process and political decisions as the product of fair and reasonable discussion and dialogue might legitimize the decisions of public authorities [32, p. 28-37]. The fall of communism provoked the development of interest in the new formula of public administration and governmental system. Self-government is perceived as the expression of the civil society because the sense of civil bounds at the local level is the strongest. In fact, the sense of civil bounds is the most noticeable within the gmina administrative unit, but it is also a characteristic feature of the other administrative units (poviat, województwo). In Poland, the main participatory institutions at the local are: local election, referendum, social consultations, civil (participatory) budget, the civil legislative initiative, and the possibility of civil participation in the debate on the report referring to the condition of the local administrative unit. In my opinion, social consultations are of special importance because young people who are under 18 years old and people who are not registered in the gmina administrative unit have the right to take part in the consultative process, which is particularly precious in the context of the civil education referring to the development of the civil society.

The dissemination of the forms of social participation at the local level in Poland is desirable because it improves the quality of representative democracy. Citizens themselves implement solutions in the area of administration, social affairs and economy through their participation in contemporary public dialogue. It is significant that in many administrative units it might be observed that the bonds between local societies and local authorities have been strengthened during last years. Public support for the realization of fundamental tasks of local administrative bodies is required in order to make the decisions legitimate and understandable. Thanks to the development of participatory forms at the local level some particular interests of political parties might be neutralized.

\section{References}

1. Bauman, Z. (1998). Globalization: The Human Consequences. New York: Columbia University Press [in English].

2. Bessette, J.M. (1980). Deliberative Democracy: the Majority Principle in Republican Government, in: How Democratic is the Constitution, Goldwin, R.A., Schambra, W.A. (eds.). Washington: American Enterprise Institute for Public Policy Research, 102-116 [in English].

3. Bożek, M. (2012). Konstytucyjne podstawy partycypacji społecznej i formy jej realizacji w samorządzie terytorialnym. Przeglad Sejmowy, 5 (112), 89-113 [in Polish].

4. Crozier, M., Huntington, S., Watanuki, J. (1975). The Crisis of Democracy: Report on the Governability of Democrcies to Trilateral Commission. New York; New York University Press [in English].

5. Dahl, R. (1982). Dilemmas of Pluralist Democracy; Autonomy vs. Control. New Haven: Yale University Press [in English].

6. Długosz, D., Wygański, J. J., (2005). Obywatele współdecydują. Przewodnik po partycypacji społecznej. Warszawa: Stowarzyszenie na Rzecz Forum Inicjatyw Pozarządowych [in Polish].

7. Dryzek, J. S., Niemeyer, S. (2006). Reconciling Pluralism and Consensus as Political Ideals. American Journal of Political Science, 50(3), 634-649 [in English].

8. Dryzek, J. S. (1990). Discursive Democracy: Politics, Policy, and Political Science. Cambridge: Cambridge University Press. [in English].

9. Dryzek, J. S. (2000). Deliberative Democracy and Beyond: Liberals, Critics, Contestations. New York: Oxford University Press [in English].

10. Dryzek, J. S. (2004). Democratic Political Theory, in: Handbook of Political Theory, Gaus, G.F., Kukathas, Ch. (eds.). London: Sage Publications, 143-154 [in English].

11. Dryzek, J. S. (2006). Deliberative Global Politics: Discourse and Democracy in a Divided Word. Cambridge: Polity Press [in English].

12. Dryzek, J. S. (2009). Democratization as Deliberative Capacity Building. Comparative Political Studies, 42(11), 1379-1402 [in English].

13. Ercan, S.A., Dryzek, J.S. (2015). The Reach of Deliberative Democracy. Policy Studies, 36(3), 241-248 [in English].

14. Fishkin, J. S. (1993). Democracy and Deliberation: New Directions for Democratic Reform. New Haven: Yale University Press [in English].

15. Fishkin, J. S. (2011). When the People Speak. Deliberative Democracy and Public Consultations. New York: Oxford University Press.

16. Fukuyama, F. (1992). The End of History and the Last Man. New York: The Free Press [in English].

17. Fukuyama, F. (2014). Political Order and Political Decay: From the Industrial Revolution to the Globalization of Democracy. New York: Ferrar, Straus \& Giroux [in English].

18. Habermas, J. (1984). The Theory of Communicative Action vol. I. Reason and the Rationalization of Society. Boston: Beacon Press [in English]. 
Sokalska E.

Ehe development of deliberative democracy and post-communist polish experience (some remarks)

19. Habermas, J. (2006). Political Communication in Media Society: Does Democracy Still Enjoy an Epistemic Dimension? The Impact of Normative Theory on Empirical Research. Communication Theory, 16(4), 411-426 [in English].

20. Huntington, S. (1991). The Third Wave. Democratization in the Late Twentieth Century. Oklahoma: Univeristy of Oklahoma Press [in English].

21. Huntington, S. (1996). The Clash of Civilizations and the Remaking of World Order. New York: Simon \& Schuster [in English].

22. Krajewska, A. (2007). Konsultacje społeczne w praktyce. Studium dwóch przypadków, in: Organizacje pozarządowe. Dialog obywatelski. Polityka państwa, Rymsza, M. (ed.). Warszawa: Instytut Spraw publicznych, 127-154 [in Polish].

23. Kuć-Czajkowska, K.A., Wasil, J. (2014). Elektroniczne oblicze władzy lokalnej w Polsce-dialog obywatelski przy użyciu narzędzi ICT, in: Dialog obywatelski: formy, mechanizmy, bariery i perspektywy rozwoju, Sienkiewicz, M.M., Sidor, M. (eds.). Lublin: Wydawnictwo Fundacji Centrum Rozwoju Lokalnego, 111-122 [in English].

24. Luhmann, N. (1991). Introduction to Systems Theory, Cambridge: Wiley-Blackwell [in English].

25. Makowski, G. (2013). Międzynarodowe standardy partycypacji publicznej na poziomie lokalnym. Analiza wybranych aktów prawa porównawczego, in: Prawo a partycypacja publiczna. Bilans monitoringu 2012, Sobiesiak-Penszko, P. (ed.). Warszawa: Instytut Spraw Publicznych, 11-23.

26. Markowski, R. (2014). Demokracja i demokratyczne innowacje. Z teoria w praktyke. Warszawa: Instytut Obywatelski, Retrieved from http://www.instytutobywatelski.pl. (September 10.2019). [in Polish].

27. Mendza-Drozd, M. (2010). Zagadnienie konsultacji społecznych w Unii Europejskiej. Analiza wybranych instytucji i dokumentów, opracowanie w ramach zleconego przez Ministerstwo Pracy i Polityki Społecznej «Badania efektywności mechanizmów konsultacji społecznych» realizowanego w ramach Programu operacyjnego Kapitał Ludzki 2007-2013 wspólfinansowanego przez Unię Europejska w ramach Europejskiego Funduszu Społecznego. Warszawa sierpień 2010, availlable at: http//www. partycypacjaobywatelska. pl/ uploads/2b_konsultacje_ue_raport.pdf (June 08.2019). [in English].

28. Rawls, J. (1999). A Theory of Justice. Revised Edition. Oxford, New York: Oxford University Press [in English].

29. Schimanek, T. (2007). Dialog obywatelski Polska 2007. Ocena wybranych instytucji dających obywatelom możliwość wptywania na podejmowanie decyzji publicznych. Warszawa: Fundacja Instytut Spraw Publicznych [in English].

30. Sidor, M. (2004). Referendum lokalnejako forma demokracji bezpośredniej, in Samorzad terytorialny w Polsce: społeczno-polityczne aspekty funkcjonowania, Michałowski, S., Pawłowska, A. (eds). Lublin: Wydawnictwo UMCS, 186-194 [in Poland.

31. Sienkiewicz, M.M., Sidor, M. (eds.) (2014). Dialog obywatelski: formy, mechanizmy, bariery i perspektywy rozwoju. Lublin: Wydawnictwo Fundacji Centrum Rozwoju Lokalnego (in Poland).

32. Sokalska, E. (2017). The Crisis of Representative Democracy - Deliberative Democracy as the Legitimization of State and Local Authorities. Law and Forensic Science. 13(1), (pp. 28-38), [in English].

33. Toffler, A. (1970).Future Shock. New York: Random House [in English].

34. Toffler, A. (1980). The Third Wave (New York: Bentam Books). [in English].

35. Tusiński, P. (2016). Prawne narzędzia upolitycznienia samorzadu terytorialnego jako przeszkody w budowaniu społeczeństwa obywatelskiego w III RP, 25 lat samorzadu terytorialnego w Polsce - bilans doświadczeń, in S. Michałowski, M. Sidor, J. Wasil (eds.). Lublin: UMCS (in Poland).

36. Ustawa $\mathrm{z}$ dnia 11 kwietnia 2001 r. o zmianie ustaw o samorządzie gminnym, o samorządzie powiatowym, o samorządzie województwa, o administracji rządowej w województwie oraz o zmianie niektórych ustaw. Journal of Laws of the Republic of Poland, 45, 497 (in Poland).

37. Ustawa z dnia 11 stycznia 2018 r. o zmianie niektórych ustaw w celu zwiększenia udziatu obywateli w procesie wybierania, funkcjonowania i kontrolowania niektórych organów publicznych. Journal of Laws of the Republic of Poland 2018, pos. 130.

38. Ustawa z dnia 22 marca 1990 r. o terenowych organach administracji ogólnejю Journal of Laws of the Republic of Poland 1990, no. 21, pos. 123.

39. Ustawa z dnia 8 marca 1990 r. o samorządzie terytorialnym. Journal of Laws of the Republic of Poland 1990, no. 16 , pos. 95 .

40. Uziębło, P. (2009). Demokracja partycypacyjna. Gdańsk: Centrum Badań Społecznychu̧u (in Poland).

41. Zychowicz Z. (2014). Konsultacje społeczne w samorządzie. Szczecin: Instytut Rozwoju Regionalnego (in Poland).

Стаття надійшла до редакції 05.12.2019. 